\title{
Pelatihan Pencegahan Bullying bagi Organisasi Kemahasiswaan di Universitas Muhammadiyah Mataram
}

\author{
Abdul Sakban*, Maemunah, Hafsah \\ Pendidikan Pancasila dan Kewarganegaraan, FKIP, Universitas Muhammadiyah Mataram \\ *Corresponding Author. Email: sakban.elfath@yahoo.co.id
}

\begin{abstract}
The service activities that have been carried out aim to provide an understanding of bullying prevention for student organizations at the Muhammadiyah University of Mataram. The implementation method used is in the form of socialization and Focus Group Discussion (FGD). The socialization method is carried out online related to the delivery of material about preventing bullying among students and the Focus Group Discussion (FGD) method is carried out online by providing education to students regarding forms of bullying and its prevention. Based on the results of the service activities that have been carried out, it can be seen that the level of student understanding of bullying prevention is high. Thus, it can be concluded that bullying prevention training activities can provide a high level of understanding among students.
\end{abstract}

\section{Article History:}

Received: 23-06-2021

Reviewed: 21-07-2021

Accepted: 13-08-2021

Published: 13-11-2021

Key Words:

Training,

Bullying,

Organization

Students.

\section{Sejarah Artikel:}

Diterima: 23-06-2021

Direview: 21-07-2021

Disetujui: 13-08-2021

Diterbitkan: 13-11-2021
Kata Kunci:
Pelatihan,
Bullying,
Organisasi
Kemahasiswaan.

How to Cite: Sakban, A., Maemunah, M., \& Hafsah, H. (2021). Pelatihan Pencegahan Bullying Bagi Organisasi Kemahasiswaan di Universitas Muhammadiyah Mataram. Jurnal Pengabdian UNDIKMA, 2(2), 211221. doi:https://doi.org/10.33394/jpu.v2i2.3893

\section{Pendahuluan}

Organisasi kemahasiswaan merupakan lembaga atau wadah untuk mengembangkan ilmu pengetahuan, ketrampilan, minat bakat dan kompetensi jasmani dan rohani. Organisasi kemahasiswaan juga dapat menjadi tempat untuk mewujudkan mahasiswa untuk belajar dalam mencapai tujuan dan cita-cita, dengan harapan mampuberpola pikir kritis yang sesuai alur logika sebagai seorang mahasiswa yang cerdas, karena masa depan bangsa dan Negara sangat ditentukan oleh kemampuan kompetensi mahasiswa. Selain itu, organisasi kemahasiswaan dapat membentuk karakter mahasiswa yang idealis, kritis, progresif, dan memiliki motivasi yang tinggi dalam mencari kebenaran keilmuan (Oviyanti, 2016). Organisasi kemahasiswaan yang ada di Universitas Muhammadiyah Mataram terdiri atas organisasi internal kampus dan organiasi eksternal kampus.Organisasi internal terdiri atas yaitu BEM, DPM, UKM Bola, UKM Musik, UKM Sasentra, UKM KSR, UKM Menwa, UKM LPM Dimensi, dan Himpunan Mahasiswa Program Studi sebanyak 23 program studi. 
Sementara organisasi eksternal yaitu IMM, HMI, PMII, LMD, SMI dan organisasi paguyuban kedaerahan.Kedua jenis organisasi kampus tersebut berfungsi sebagai wadah untuk mengembangkan bakat, minat dan kemampuan mahasiswa dari berbagai ilmu pengetahuan dan teknologi.

Studi penelitian sebelumnya telah dilakukan beberapa peneliti lainnya tentang pencegahan bullying, diantaranya Aminah (2019) melakukan kegiatan sosialisasi perilaku bullying dengan melibatkan orang tua, kader kesehatan, dan anak-anak TK, dampaknya masyarakat memahami tentang bullying tersebut. Aminah (2020) menemukan bahwa sosialisasi bullying media social berupa fitur youtuber selama 5 hari berturut dimana dalam lima hari tersebut cukup banyak masyarakat yang menonton video pencegahan bullying. Penyuluhan dan pelatihan Respect Education bagi guru dan orang tua murid TK dalam pencegahan dan penanganan bullying serta perlu dilakukan pendampingan lebih intensif utk mengurangi kejahatan bullying (Pujiyanti, 2021). Sakban, et al (2018) menemukan bahwa perlu etika berinternet, peran orang tua harus lebih intensif mengawasi perkembangan anaknya terhadap pengaruh media internet, aparat sipil kepolisian rutin melakukan kampanye "anti bullying" (stop bully) di sekolah, kampus/instansi dan masyarakat, dan melibatkan organisasi social untuk mengawasi peredaran kejahatan cyberbullying. Cara mencegah dan mengurangi berbagai tindakan bullying di media sosial dapat memaksimalkan sikap etika berinternet, peningkatan peran orang tua lebih intensif, pihak kepolisian rutin melakukan kegiatan sosialisasi dan penyuluhan anti bullying, dan organisasi social. Sakban et al (2018) menemukan bahwa peran polisi dalam pencegahan cyberbullying dilakukan berupa kegiata yaitu sosialisasi pada lembaga pendidikan, instansi dan tempat umum, beretika dalam berkomunikasi di media social. Sakban et al (2019) untuk memberikan efek jera kepada pelaku kejatan bullying maka hal yang dilakukan apara hukum yaitu aparat penegak hukum berupa KUHP dan Undang-Undang No. 8 Tahun 2018 tentang Informasi Teknologi Elektronik dengan melihat isi penjelasan pasal demi pasal dan konten kejahatan yang dilakukan oleh pelaku. Sakban et al (2020) menemukan bahwa penerapan metode represif dapat mengefektifkan aparat penegak hukum dalam menuntaskan kejahatan cyber-bullying. Sakban et al (2020) menjelaskan juga bahwa untuk pencegahan kejahatan cyber perlu dilakukan pengawasan yang ketat di internet dan perlu ada system keamanan yang efektif.

Beberapa hasil penelitian dan berbagai literature yang relevan bahwa penelitian cyber bullying atau bullying lebih focus pada aspek pencegahan secara umum, kebijakan hukum cyber bullying, perilaku bullying, metode represif terhadap bullying dan peran badan sandi Negara dalam mengawasi kejahatan cyber bullying. Sementara aspek kajian artikel pengabdian kepada masyarakat tentang pelatihan pencegahan bullying bagi organisasi kemahasiswaan di Universitas Muhammadiyah Mataram. Karena organisasi kemahasiswaan ini perlu dilakukan pembinaan, pelatihan tentang pencegahan bullying.

Organisasi binaan Wakil Rektor III Universitas Muhammadiyah Mataram yaitu BEM, DPM, UKM Bola, UKM Musik, UKM Sasentra, UKM KSR, UKM Menwa, UKM LPM Dimensi, dan Himpunan Mahasiswa Program Studi sebanyak 23 program studi serta IMM setiap fakultas. Beberapa organisasi kemahasiswaan tersebut, berdasarkan hasil observasi dan pengamatan penulis menunjukkan organisasi kemahasiswa menginginkan adanya pelatihan preventif cyber bullying, isu hoax, dan penipuan onine karena kita sekarang berada pada jaman milenial, era industry 4.0 yang dimana setiap kegiatan berbasis teknologi canggih. Adanya teknologi canggih tersebut memberikan dampak positif dan negative kepada mahasiswa. Dampak negatif berupa 1) beberapa mahasiswa tidak bisa membedakan yang mana berita faktualdan berita bohong yang tercantum dalam media social, 2) media social 
seperti Facebook, Instagram, WhatshApp, dan E-mail sebagai sumber informasi dan alat komunikasi antara mahasiswa satu dengan mahasiswa lainnyadapat dijadikan sebagai alat untuk menyiarkan perilaku tindak pidana berupa membuli teman, memposting aktivitas orang lain yang tidak factual, mencaci maki orang lain, menjelekkan orang lain, dan penipuan online, 3) dampak psikologis kepada korban bullying akan menyebabkan korbanmerasa malu kepada temannya, minder dan bahkan kurang percaya diri bahwa perbuatan itu bukanlah perbuatannya. Misalnya ada dosen yang melarang mahasiswa untuk berorganisasi karena harus ikut kuliah.Kalimat larangan chating dosen tersebut kepada mahasiswa dimuatlah oleh salah satu organisasi internal kampus untuk disebarkan di media social dan sangat viral di baca oleh public baik dilingkungan kampus maupun diluar kampus. Sementara dampak positif yaitu dapat menyampaikan informasi factual, hayalan, hoax secara cepat, dapat membantu mahasiswa menambah referensi perkuliahan, dapat menyimpan data-data tugas mahasiswa, dapat mengirimkan tugas mahasiswa secara online, dan dapat berbisnis secara online.

Hasil wawancara dengan Kabag kemahasiswaan Universitas Muhammadiyah Mataram menjelaskan sebagian organisasi kemahasiswaan di kampus khsususnya adik-adik UKM telah melewati batas etika dalam berkomunikasi dengan para pimpinan khususnya bagian kemahasiswaan terkait program dan proposal yang diajukan ke bagaian kemahasiswaan banyak kami tahan karena program yang diajukan tidak kontekstual dengan visi misi Universitas. Akibatnya karena proposal dan program kemahasiswa ditolak, mereka membuat tulisan di media local kampus, media sosial dengan membuli para pimpinan dengan kalimat-kalimat tidak etis, misalnya kampus kapitalisme terhadap program kemahasiswaan dan hak mahasiswa untuk berorganisasi dibatasi.Untuk itu, saran kami perlu adanya sosialisasi kepada organiasasi kemahasiswaan pentingnya perilaku bullying disampaikan kepada mereka, agar kedepan organisasi mahasiswa ini dapat dipercaya sebagai agen perubahan karakter.Selain itu, sebagian mahasiswa Universitas di Kota Surabaya secara keseluruhan terdapat perilaku bullying pada mahasiswa dan perilaku bullying yang banyak terjadi yaitu perilaku bullying pada jenis verbal, isyarat, dan pengucilan sedangkan perilaku bullying jenis fisik, pemalakan, dan cyberbullying kecil terjadi pada mahasiswa terdapat peran yaitu pelaku bullying (49\%), asisten bully (45\%), korban (61\%), pengikut (52\%), pembela (75\%), dan penonton yang tidak perduli (61\%) (Hapsari 2016). Aisyah (2018) juga menemukan bahwa ketika revenge motive meningkat, maka perilaku cyberbullying juga meningkat. Menurut data KPAI kasus bullying yang terlaporkan di 201937 kasus. Bukan hanya bullying terhadap sesama teman, bahkan di 2018 di Gresik pernah terjadi bullying terhadap seorang guru yang di video kemudian menjadi viral(IMM, 2020).Demikian pula Affarah, dkk, (2019) menjelaskan bullying dapat memberikan dampak buruk yang berat pada korban berupa gangguan belajar, gangguan mental, gangguan fisik, dan masalah kesehatan serta psikososial lain. Di beberapa negara, bullying berkontribusi besar terhadap angka kejadian bunuh diri pada remaja.

Berbagai masalah tersebut, mendorong Mitra Wakil Rektor III Universitas Muhammadiyah Mataram sebagai wadah pembinaan kemahasiswaan pada bidang Al Islam dan Kemuhammadiyahan serta bidang minat dan bakat kemahasiswaan untuk tetap menjalankan program penguatan keorganisasian sehingga roda organisasi kemahasiswaan berjalan efektif. Eksistensi mitra ini dalam pengabdian kepada masyarakat melalui programpelatihan pencegahan bullying bagi organisasi kemahasiswaan di Universitas Muhammadiyah Mataram, Pertama, dapat memberikan wawasan ilmu pengetahuan bagi mahasiswa maupun organisasi kemahasiswaan tentang bahaya bullying di media social, cara 
tindakan pencegahan cyber bullying. Kedua, dapat menjadi pedoman bagi mitra dalam membina mahasiswa dan organisasi kemahasiswaan serta calon mahasiswa di era industry 4.0 melalui kampanye stop bullying malalui sosialisasi offline dan online. Ketiga, dapat mengurangi terjadinya tindakan criminal mahasiswa sehingga citra mahasiswa sebagai orang terpelajar terjaga dengan baik. Adapun permasalahan dari mitra sebagai berikut:

a) Kurangnya pembinaan terhadap organisasi kemahasiswaan tentang bahaya dan dampak bullying

b) Kurangnya pemahaman mahasiswa dalam bermedia social sesuai tuntunan etika komunikasi menurut Undang-Undang ITE

c) Kurangnya sosialisasi stop bullying bagi mahasiswa yang dilakukan oleh mitra

d) Belum adanya pelatihan bagi mahasiswa dan organisasi kemahasiswaan cara pencegahan bullying di lingkungan kampus Universitas Muhammadiyah Mataram.

Pengabdian yang telah dilakukan bertujuan untuk memberikan pemahaman tentang pencegahan bullying bagi organisasi kemahasiswaan di Universitas Muhammadiyah Mataram. Adanya peltihan ini sangat penting dilakukan untuk memberikan pemahaman dan sosialisasi tentang perilaku bullying bagi kalangan mahasiswa, adanya kegiatan ini dapat mengurangi kejahatan bullying bagi mahasiswa khususnya untuk lembaga kemahasiswaan.

\section{Metode Pengabdian}

Metode yang digunakan dalam kegiatan pelatihan ini adalah (1) Focus Group Discussion (FGD). Focus Group Discussion (FGD) dilakukan oleh semua tim pengabdian, dimana anggota tim ada yang bertugas sebagai moderator, notulen, dan observer. (2) Edukasi. Edukasi dilakukan untuk mneyampaikan bentuk bullying dan pencegahannya kepada mahasiswa dan organisasi kemahasiswaan melalui kegiatan penyuluhan dan diskusi aktif.

\section{a) Rencana Kegiatan Pelatihan}

Rencana kegiatan pelatihan melalui tahapan-tahapansebagai berikut:

1) Tahap persiapan

Tahap persiapan initim pengabdian melakukan telusur pustaka tentang kondisi bullying di Indonesia pada umumnya dan di Mataram pada khususnya. Kemudian tim pengabdian memilih 31 (tiga puluh satu) organisasi kemahasiswaan di Universitas Muhammadiyah Mataram dengan karakteristik prestasi akademik, latar belakang tingkat ekonomi, dan latar belakang sosial budaya yang heterogen. Selanjutnya tim menyiapkan materi, alatalat dan bahan yang diperlukan untuk skrining bullying. Materi yang disiapkan meliputi: a) Pembuatan kuisioner untuk wawancara mendalam (in-depth interview) kepada ketua organisasi, b) Pembuatan kuisioner untuk focused group discussion (FGD) kepada perwakilan mahasiswa.

2) Tahap intervensi

Pada tahap intervensi, tim turun ke lapangan bersama-sama dan melakukan skrining dengan metode yang telah disiapkan secara bersama-sama sebagai satu kesatuan, tidak membagi diri. Setiap kegiatan wawancara mendalam dan FGD dilakukan oleh semua tim pengabdian, dimana anggota tim ada yang bertugas sebagai moderator, notulen, dan observer. Kegiatan wawancara mendalam dan FGD juga menggunakan alat bantu tape recorder agar hasil wawancara dan FGD tidak ada yang terlewat dari pengamatan tim pengabdian. Dari hasil skrining, jika terdapat mahasiswa yang terindikasi mengalami bullying (korban), atau melakukan bullying (pelaku) akan diberikan waktu untuk berkonsultasi kepada psikiater yang juga menjadi tim pengabdian. 
3) Tahap edukasi

Tahap edukasi dalam bentuk penyuluhan dan diskusi aktif.

4) Tahap evaluasi

Tahap evaluasi dalam kegiatan ini adalah melakukan monitoring terhadap pelaksanaan kegiatan sejauhmana efektivitasnya kegiatan pelatihan pencegahan bullying terhadap organisasi kemahasiswaan Universitas Muhammadiyah Mataram untuk keberlanjutan program pelatihan berikutnya.

b) Partisipasi Mitra Dalam Pelaksanaan Program

Partisipasi mitra dalam pelaksanaan program pelatihan pencegahan bullying bagi organisasi kemahasiswaan di Universitas Muhammadiyah Mataram adalah sebagai berikut:

1) Menyediakan tempat kegiatan pelatihan

2) Mengundang organisasi kemahasiswaan dan perwakilan mahasiswa

3) Membantu pelaksanaan kegiatan hingga selesai

4) Membantu mengevaluasi pelaksanaan kegiatan program pelatihan

5) Dapat memberikan pembinaan soft skill kepada mahasiswa dan organisasi kemahasiswaan dalam bidang informasi dan teknologi elektronik

6) Dapat memberikan pemahaman bagimahasiswa dan organisasi kemahasiswaan

\section{Hasil Pengabdian dan Pembahasan}

Pelaksanaan kegiatan pengabdian kepada masyarakat telah dilakukan selama kurun waktu 6 bulan terhitung mulai tanggal 15 April 2020 sampai dengan 15 September 2020 melalui tahapan-tahapan yakni tahap persiapan, tahap intervensi, tahap edukasi dan tahap evaluasi.

\section{Tahap persiapan}

Pada tahap persiapan ini tim pengabdi melakukan penelusuran pustaka tentang kondisi bullying di Indonesia pada umumnya dan di Mataram pada khususnya. Kemudian tim pengabdian memilih 31 (tiga puluh satu) organisasi kemahasiswaan di Universitas Muhammadiyah Mataram dengan karakteristik prestasi akademik, latar belakang tingkat ekonomi, dan latar belakang sosial budaya yang heterogen. Selanjutnya tim menyiapkan materi, alat-alat dan bahan yang diperlukan untuk skrining bullying. Materi yang disiapkan meliputi: a) Pembuatan kuisioner untuk wawancara mendalam (in-depth interview) kepada ketua organisasi, b) Pembuatan kuisioner untuk focused group discussion (FGD) kepada perwakilan mahasiswa. Berikut dokumentasi bentuk kuisioner yang digunakan untuk melakukan wawancara dan FGD dengan organisasi kemahasiswaan.

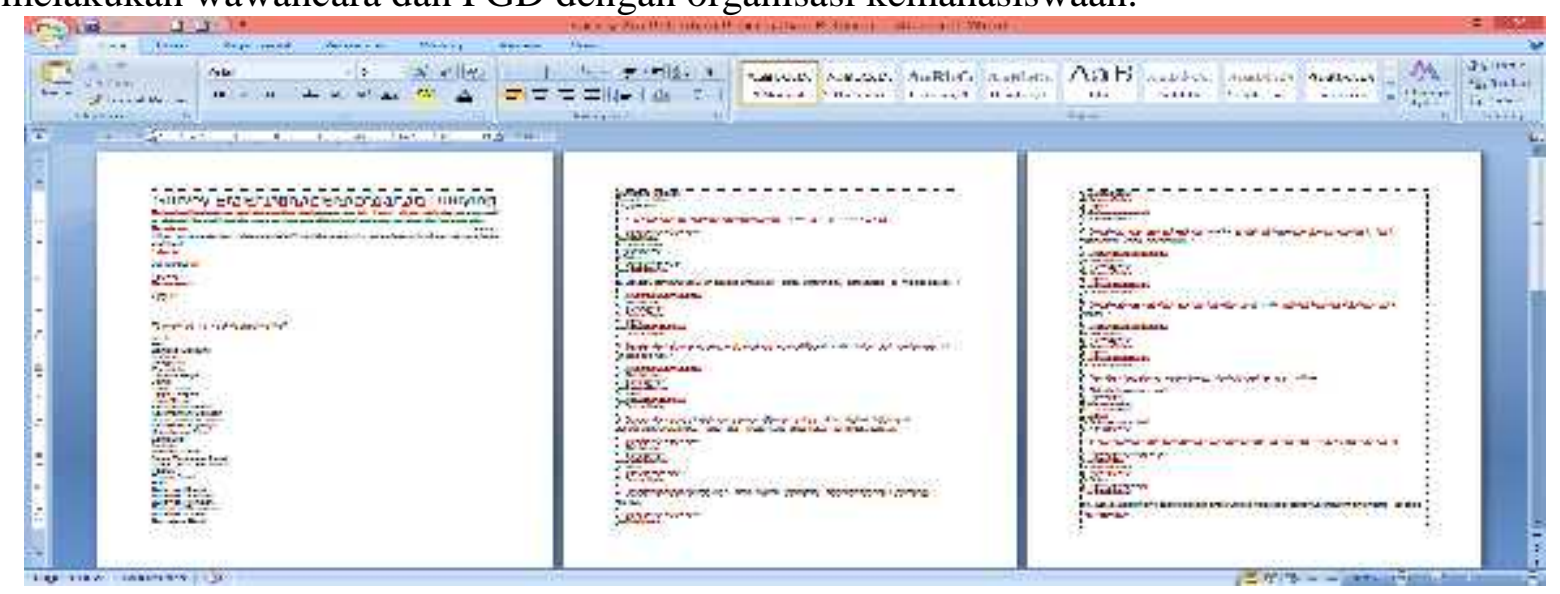

Gambar 1. Bentuk Kuisioner untuk Wawancara dan FGD 


\section{Tahap intervensi}

Pada tahap intervensi, tim pengabdi turun ke lapangan bersama-sama dan melakukan skrining dengan metode yang telah disiapkan secara bersama-sama sebagai satu kesatuan, tidak membagi diri. Setiap kegiatan wawancara mendalam dan FGD dilakukan oleh semua tim pengabdian, dimana anggota tim ada yang bertugas sebagai moderator, notulen, dan observer. Kegiatan wawancara mendalam dan FGD juga menggunakan alat bantu tape recorder agar hasil wawancara dan FGD tidak ada yang terlewat dari pengamatan tim pengabdian. Dari hasil skrining, jika terdapat mahasiswa yang terindikasi mengalami bullying (korban), atau melakukan bullying (pelaku) akan diberikan waktu untuk berkonsultasi kepada psikiater yang juga menjadi tim pengabdian. Berikut dokumentasi kegiatan wawancara secara daring yang telah dilakukan kepada mahasiswa.

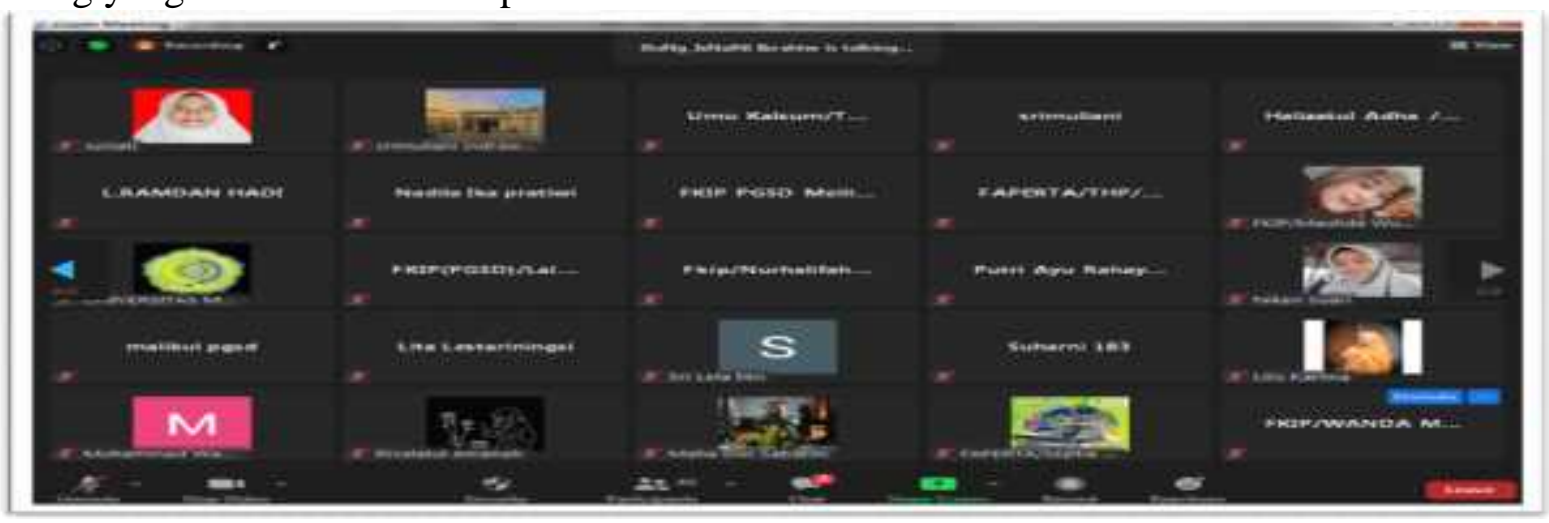

\section{Tahap edukasi}

Gambar 2. Dokumentasi Kegiatan Wawancara dengan Mahasiswa

Pada tahap edukasi ini telah dilakukan kegiatan penyuluhan dan diskusi aktif dengan mahasiswa via daring dengan tujuan untuk memberikan pemahaman kepada mahasiswa terkait pencegahan bullying pada tingkat organisasi kemahasiswaan yang ada di Universitas Muhammadiyah Mataram. Narasumber dalam tahap edukasi ini meliputi: Abdul Sakban, M.Pd sebagai pemateri pertama dalam pembahasan tentang "Bentuk bullying, Perilaku, Korban bullying dan Penanganan bullying". Dr. Hj. Maemumah, M.H sebagai pemateri kedua membahas tentang "Pencegahan bullying, penjelasan pasal-pasal tentang tindak pidana bullying dan penjelasan UU ITE". Hafsah, M.Pd sebagai pemateri ketiga membahas terkait "Dampak psikologis korban bullying". Berikut dokumentasi kegiatan penyuluhan dan diskusi aktif yang telah dilakukan.

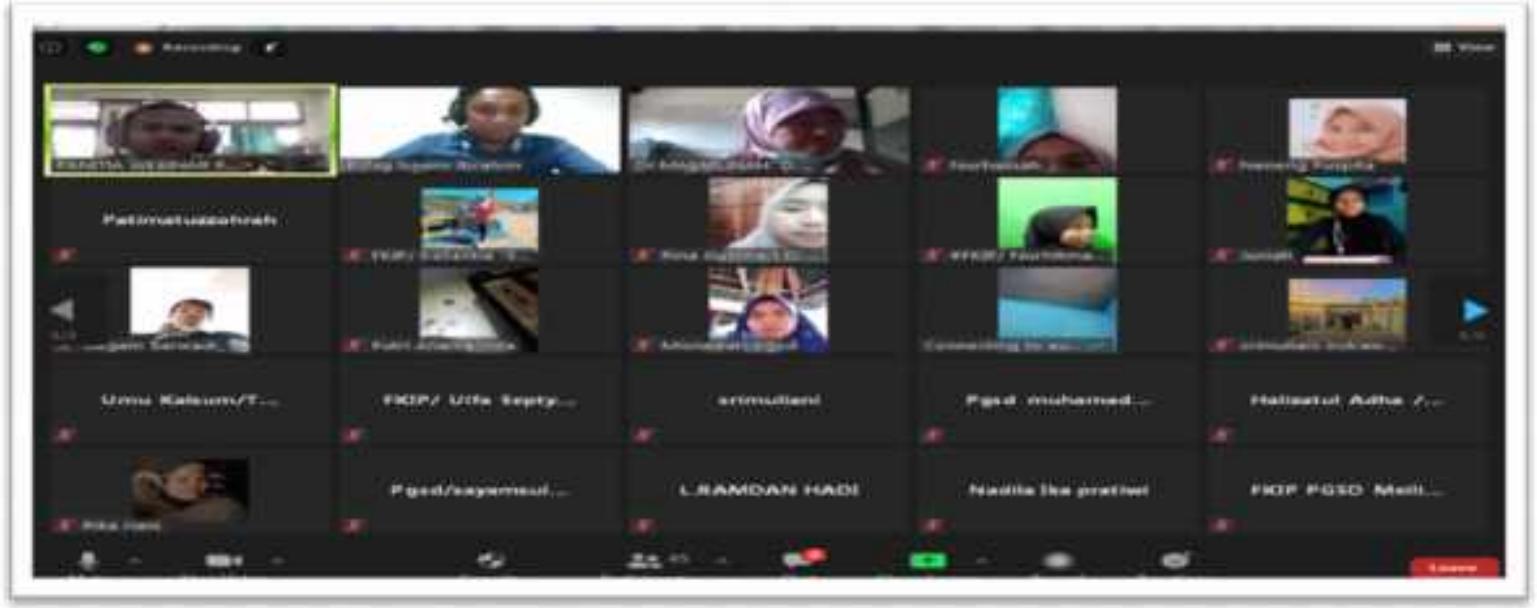




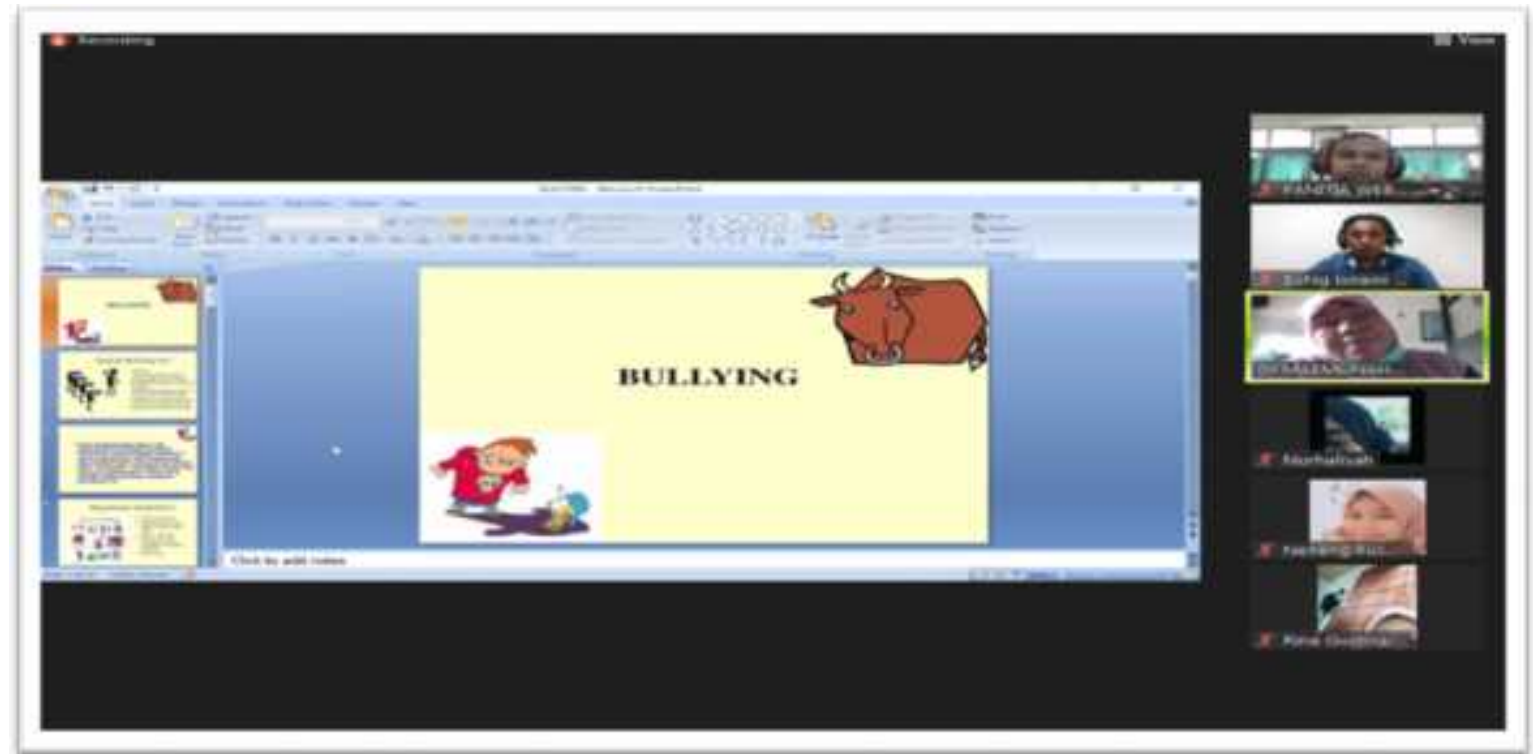

Gambar 3. Dokumentasi Kegiatan Edukasi dengan Mahasiswa

Setelah ketiga narasumber memaparkan materinya, maka moderator memberikan kesempatan kepada mahasiswa untuk bertanya. Sesi pertanyaan dibuka dalam 3 termin dikarenakan sangat antusiasnya mahasiswa yang ingin bertanya dan ingin mengetahui lebih jelas terkait teknik pencegahan bullying di tingkat mahasiswa yang efektif untuk diterapkan. Selanjutnya, para narasumber diberikan kesempatan untuk menjawab pertanyaan dari peserta kegiatan. Adapun dokumentasi kegiatan Tanya-jawab yang telah dilakukan sebagai berikut.
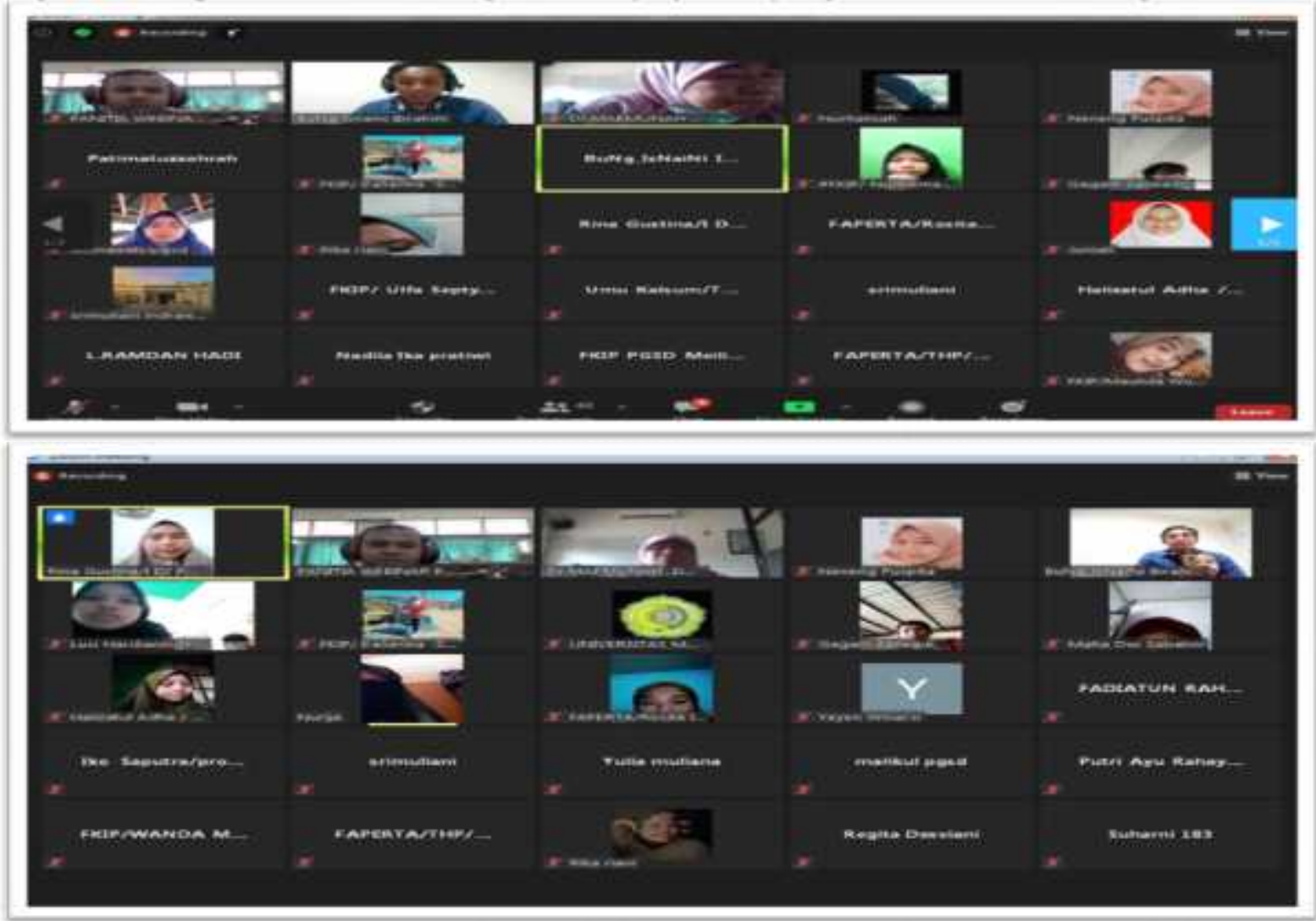

Gambar 4. Dokumentasi Kegiatan Tanya-Jawab Peserta 


\section{Tahap evaluasi}

Tahap evaluasi dalam kegiatan ini adalah melakukan monitoring terhadap pelaksanaan kegiatan sejauhmana efektivitasnya kegiatan pelatihan pencegahan bullying terhadap organisasi kemahasiswaan Universitas Muhammadiyah Mataram untuk keberlanjutan program pelatihan berikutnya.

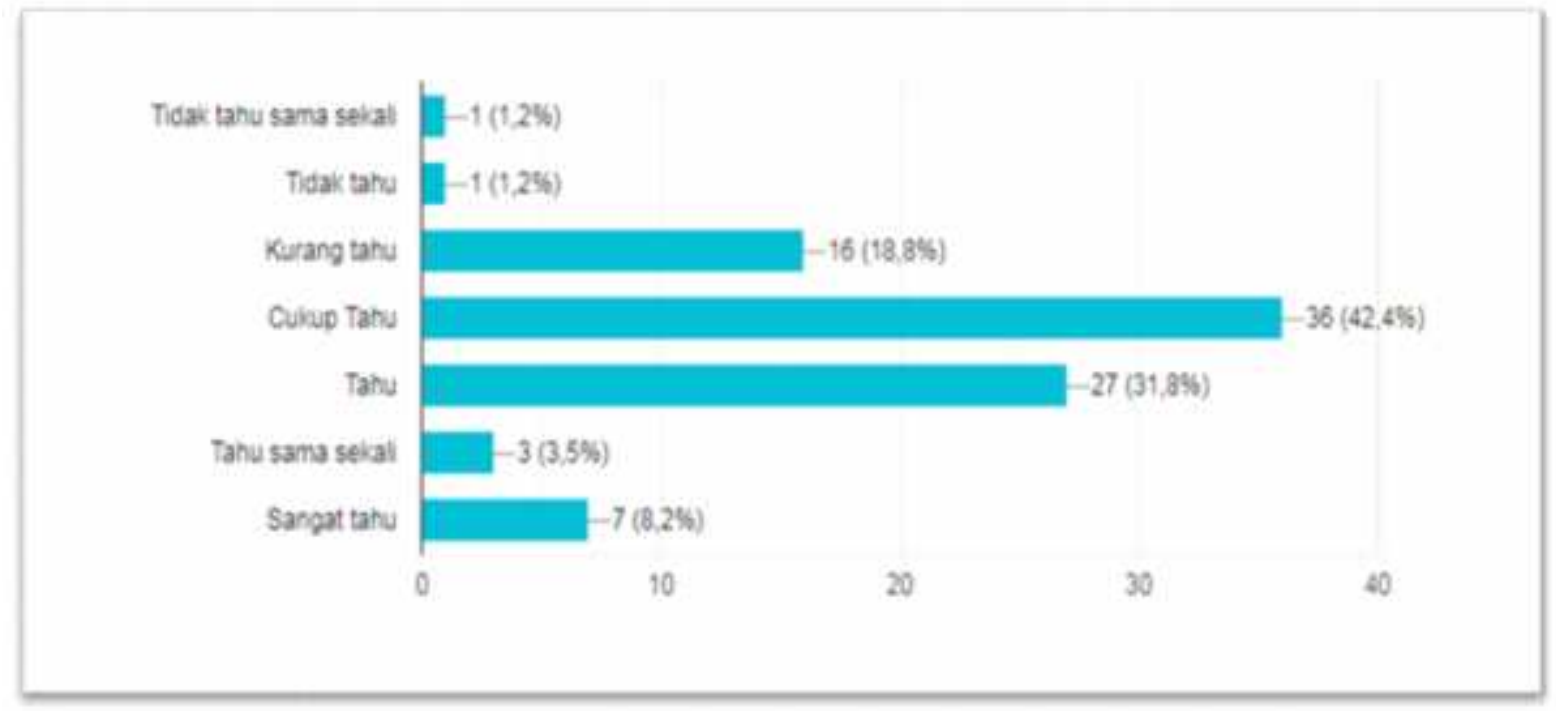

\section{Grafik 1. Persentase Pemahaman Mahasiswa Sebelum Pelatihan}

Berdasarkan hasil evaluasi pelaksanaan pelatihan pencegahan bullying bagi organisasi kemahasiswa di Universitas Muhammadiyah Mataram terdapat skor nilai pemahaman mahasiswa terhadap fitur bullying di media social sebelum pelaksanaan pelatihan mencapai 42,4\% dengan kategori cukup paham, sedangkan yang tahu/paham mencapai 31,8\% dan 18,8\% lainnya kurang tahu/paham. Dengan hal tersebut maka perlu dilakukan pelatihan pencegahan bullying bagi organisasi kemahasiswaan.

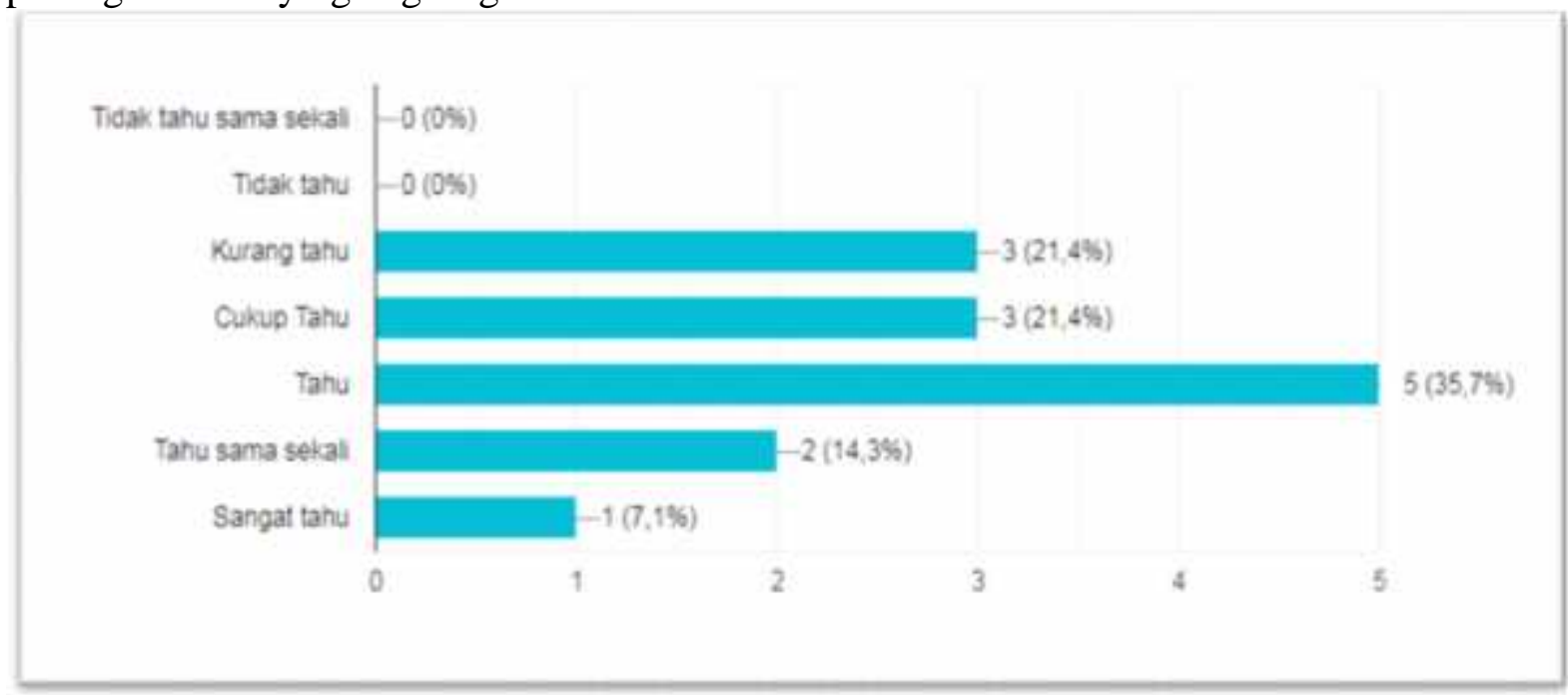

\section{Grafik 2. Persentase Pemahaman Mahasiswa Setelah Pelatihan}

Hasil evaluasi setelah dilakukan pelatihan pencegahan bullying bagi organisasi kemahasiswa terdapat peningkatan pemahaman mahasiswa yaitu mencapai 35,7\% dengan kateogi tahu/paham, kategori cukup tahu/paham mencapai $21,4 \%$, kategori kurang tahu mencapai $21,4 \%$. Jadi dampak adanya pelatihan pencegahan ini sangat memberikan 
pengetahuan kepada mahasiswa berupa teknik pencegahan, bentuk-bentuk bullying dan etika komunikasi di internet. Adapun dokumentasi kegiatan evaluasi yang telah dilakukan sebagai berikut.
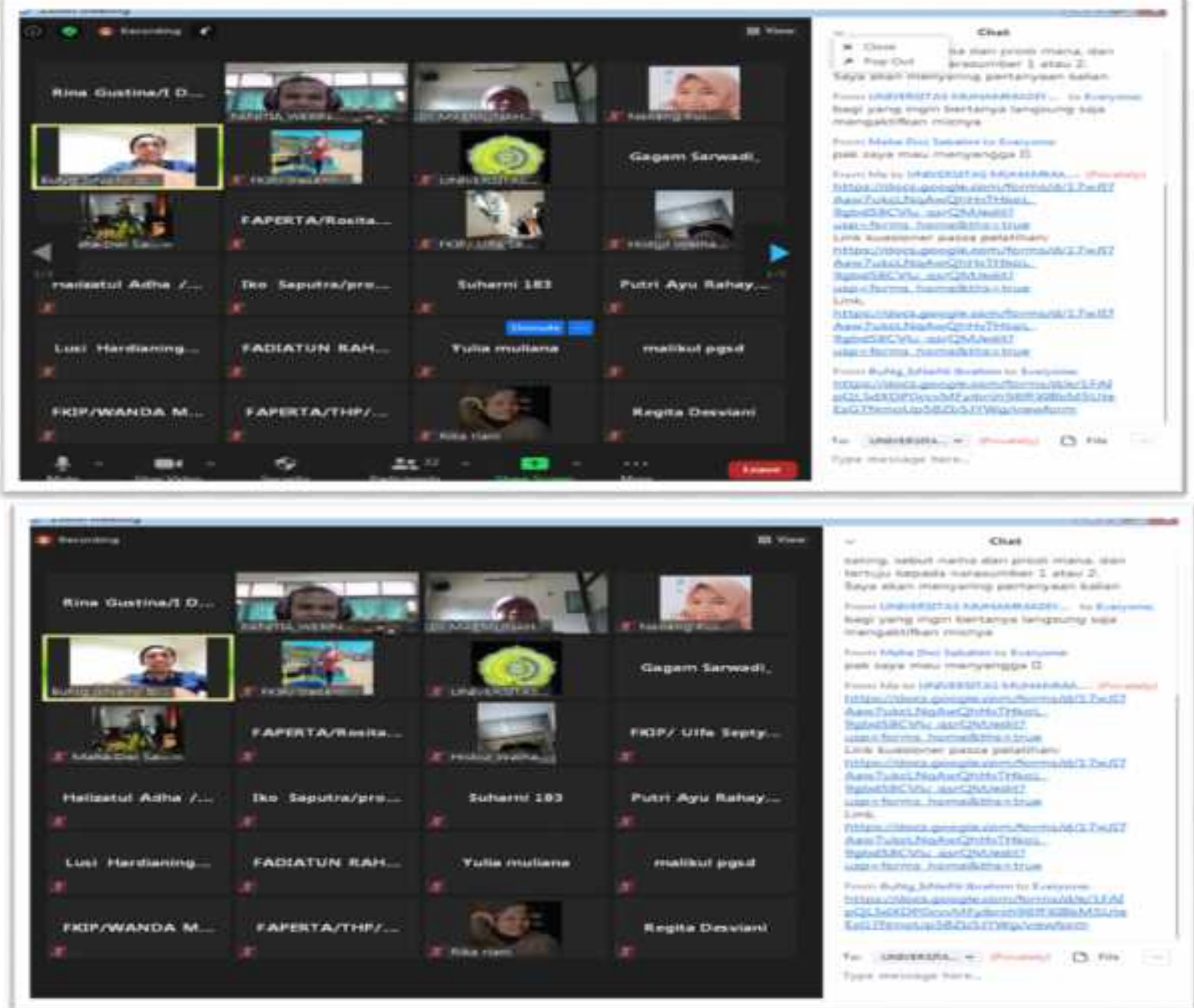

Gambar 5. Dokumentasi Kegiatan Evaluasi

Adapun rencana tindak lanjut dalam kegiatan ini yaitu memberikan rekomendasi kepada pimpinan perguruan tinggi untuk memberikan pembinaan, sosialisasi dan pemberdayaan tentang bullying baik pencegahan maupun bentuk bullying untuk dilakukan setiap tahunnya agar mahasiswa tidak terprovokasi dengan berita hoax, bullying di media social. Selain itu, mahasiswa harus berhati-hati dalam melakukan komunikasi di media social agar tidak menjadi korban bullying maupun pelaku bullying karena era industry 4.0 ini semua serba teknologi mulai pesan makanan maupun pesan rapat atau aktivitas belajar dan lainnya.

\section{Kesimpulan}

Secara keseluruhan kegiatan pengabdian yang telah dilakukan dapat disimpulkan berjalan lancar. Hal ini terlihat kegiatan pengabdian yang telah dilakukan terlihat bahwa tingkat pemahaman mahasiswa terhadap pencegahan bullying tinggi. Dengan demikian dapat disimpulkan bahwa kegiatan pelatihan pencegahan bullying dapat memberikan pemahaman yang tinggi di kalangan mahasiswa. 


\section{Saran}

Pelatihan pencegahan bullying bagi organisasi kemahasiswaan memberikan saran kepada Pimpinan Perguru Tinggi untuk memberikan pembinaan tentang perilaku bullying agar mahasiswa tahu dan paham mana berita bullying maupun sebaliknya. Untuk mahasiswa, dalam berkomunikasi di media social perlu dilakukan secara cermat, teliti agar tidak menjadi korban bullying maupun pelaku bullying. Pemerintah perlu adanya kegiatan pelatihan ini agar mahasiswa dapat secara menghindari dari kejatahan bullying di tingkat kemahasiswaan.

\section{Daftar Pustaka}

Aisyah Aulia Rahim.(2018) Motif Balas Dendam (Revenge Motive) dan Anonimitas Sebagai Prediktor Perilaku Perundungan Dunia Maya (Cyberbullying) pada Mahasiswa di Kota Surabaya. Skripsi, Universitas Airlangga.(Online, http://repository.unair.ac.id/73368/ diakses 24 April 2020).

Aminah, T., Puspitaning, D., Nadia, T., \& Antika, D. S. (2019). Sosialisasi dan Pencegahan Perilaku Kekerasan/Bullying pada Anak Usia Sekolah Dasar di Desa Jatisari Kec. Pakisaji Kab. Malang. Skripsi, Technical Report. Poltekkes RS dr. Soepraoen, Malang

Aminah, T., Handayani, A. F., Khasanah, A. N., \& Savera, A. S. N. (2020). Stop Perilaku Kekerasan/Bullying pada Remaja Melalui Media Sosial. Skripsi, Technical Report. Poltekkes RS dr. Soepraoen, Malang

Centers for Disease Control and Prevention.(2016). Understanding Bullying Factsheet 2016. Available from: https://www.cdc.gov/violenceprevention/pdf/bullying factsheet.pdf

Devisi Pengembangan Penelitian dan Devisi Pengabdian Kepada Masyarakat.(2019). Buku Panduan Usulan Proposal dan Laporan Hasil Penelitian dan Pengabdian Kepada Masyarakat Tahun 2019. Lembaga Penelitian dan Pengabdian kepada Masyarakat (LPPM) Universitas Muhammadiyah Mataram.

Gini G, Pozzoli T, 2009. Association Between Bullying and Psychosomatic Problems: A Meta-analysis. Pediatrics ; 123: p.1059-1065 www.pediatrics.org

Hapsari, Dyah D. (2016). Perilaku Bullying pada Mahasiswa Fakultas Bahasa dan Seni (FBS) di Universitas Negeri Surabaya. Jurnal Mahasiswa Bimbingan Konseling UNESA, Vol. 6, No. 3.

Ikatan Mahasiswa Muhammadiyah. (2020). Living Value Education Sebagai Penangkal Bullying. Artikel, (Online, https://www.imm.or.id/blog-classic/ diakses 24 April 2020).

I Wahyu Sulistya Affarah, Emmy Amalia, Lina Nurbaiti, Hamsu Kadriyan, Pujiarohman.(2019). Public Sharing on Prevention and Impact of Bullying in Adolescents. Seminar Nasional Pengabdian kepada Masyarakat Prosiding PEPADU LPPM Universitas Mataram, Vol. 1.

Laeheem, K. (2013). Family and upbringing background of students with bullying behavior in Islamic private schools, Pattani province, Southern Thailand. Asian Social Science, 9(7), 162.

Marpuajian, 2018.Cyberbullying. Artikel, (Online, https://mycyberbullying.wordpress.com/author/marpuahjian/diakses 18 Agustus 2018).

Othieno, C. J., Okoth, R. O., Peltzer, K., Pengpid, S., \& Malla, L. O. (2014). Depression among university students in Kenya: Prevalence and sociodemographic correlates. Journal of affective disorders, 165, 120-125. 
Oviyanti, F. (2016). Peran organisasi kemahasiswaan intrakampus dalam mengembangkan kecerdasan interpersonal mahasiswa. El-Idare: Jurnal Manajemen Pendidikan Islam, 2(1).

Pujiati, D., \& Wulandari, D. A. (2021, February). Respect Education Bagi Guru Sebagai Upaya Pencegahan Bullying Di TK Aisyiyah Busthanul Athfal Kebanggan Banyumas 2020. In Prosiding Seminar Nasional LPPM UMP (pp. 307-311).

Rastati, R. (2016). Bentuk perundungan siber di media sosial dan pencegahannya bagi korban dan pelaku. Jurnal Sosioteknologi, 15(2), 169-186.

Sakban, A., Sahrul, S., Kasmawati, A., \& Tahir, H. (2018). The Role of Police to Reduce and Prevent Cyber-bullying Crimes in Indonesia. In 1st International Conference on Indonesian Legal Studies (ICILS 2018). Atlantis Press.

Sakban, A., Sahrul, S., Kasmawati, A., \& Tahir, H. (2018). Tindakan Bullying di Media Sosial dan Pencegahannya. JISIP (Jurnal Ilmu Sosial dan Pendidikan), 2(3).

Sakban, A., Sahrul, A. K., \& Tahir, H. (2020). The Implementation Repressive Method to Solving of Cyber-Bullyingin the West Nusa Tenggara.

Sakban, A., Kasmawati, A., \& Tahir, H. (2020). The role of Indonesian National Cyber Bureau in monitoring mining business companies. In IOP Conference Series: Earth and Environmental Science (Vol. 413, No. 1, p. 012032). IOP Publishing.

Sakban, A., Sahrul, A. K., \& Tahir, H. (2019). Police Preventative Against Cyber-Bullying Crimes In Indonesia. International Journal Of Scientific \& Technology Research, Volume 8, Issue 12.

Sakban, A., Sahrul, Andi Kasmawati, Heri Tahir. (2020). The Implementation Repressive Method to Solving of Cyber-Bullyingin the West Nusa Tenggara. International Journal of Advanced Science and Technology, 29(05), 13414-13421. Retrieved from http://sersc.org/journals/index.php/IJAST/article/view/25989 